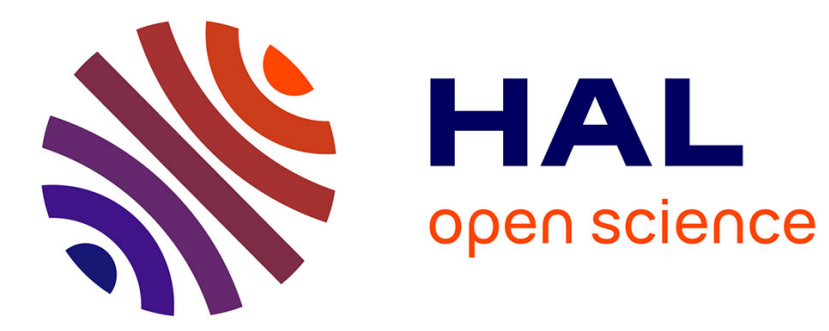

\title{
Formal entrepreneurial networks as communities of practice: a longitudinal case study
}

Vincent Lefebvre, Miruna Radu Lefebvre, Eric Pierre Simon

\section{To cite this version:}

Vincent Lefebvre, Miruna Radu Lefebvre, Eric Pierre Simon. Formal entrepreneurial networks as communities of practice: a longitudinal case study. Entrepreneurship and Regional Development, 2015, 27 (7-8), pp.500-525. 10.1080/08985626.2015.1070539 . hal-01217308

\section{HAL Id: hal-01217308 \\ https://hal-audencia.archives-ouvertes.fr/hal-01217308}

Submitted on 19 Oct 2015

HAL is a multi-disciplinary open access archive for the deposit and dissemination of scientific research documents, whether they are published or not. The documents may come from teaching and research institutions in France or abroad, or from public or private research centers.
L'archive ouverte pluridisciplinaire HAL, est destinée au dépôt et à la diffusion de documents scientifiques de niveau recherche, publiés ou non, émanant des établissements d'enseignement et de recherche français ou étrangers, des laboratoires publics ou privés. 
Formal entrepreneurial networks as communities of practice: a longitudinal case study

\author{
Vincent Lefebvre \\ Audencia, Nantes, France \\ 8 route de la Jonelière - B.P. 31222 - 44312 Nantes Cedex 3 \\ + 33 (2) 40378140 \\ vlefebvre@audencia.com \\ Miruna Radu Lefebvre \\ Audencia, Nantes, France \\ 8 route de la Jonelière - B.P. 31222 - 44312 Nantes Cedex 3 \\ +33(2) 40373466 \\ mradu@audencia.com
}

Eric Simon $\uparrow$

ISC Paris Business School, France

22, bd du Fort de Vaux, 75017 Paris 


\title{
Formal entrepreneurial networks as communities of practice: a longitudinal case study
}

\begin{abstract}
This article argues that entrepreneurial learning is genuinely connected to entrepreneurial networking activities, within a co-evolving dynamics. We take a longitudinal network approach to study the combined development of network dynamics and learning in a French formal entrepreneurial network over a period of four years (2005-2009). Our aim is to extend our knowledge of entrepreneurial learning emphasised both as a process and an outcome of social interaction, by focussing on the interplay between network evolution and the changing learning needs of participants over time. Building on a situated social perspective of entrepreneurial learning, we demonstrate that network learning processes and outcomes are contingent on the progressive network transformation from a social network to a community of practice.
\end{abstract}

Keywords: formal entrepreneurial network; learning; community of practice

\section{Introduction}

Learning has been emphasized as a major issue of entrepreneurial networks (Xiao, Marino and Zhuang 2010; Politis 2005), yet we know little about the social interaction processes linking network dynamics to learning processes and outcomes (Bergh 2009; Cohendet and Llerna 2010; Parker 2008). We take a dynamic process approach to study the building and evolution of one of the most important formal entrepreneurial networks in France, the Entrepreneurs' Club of the Paris Chamber of Commerce. Formal entrepreneurial networks are policy-led organisations aimed at sustaining entrepreneurship ${ }^{1}$ development at a regional or national level by providing participants with a practical means to increase the variety and number of their social

\footnotetext{
${ }^{1}$ We use the word 'entrepreneurship' here to designate not only the start-up process but also enterprise growth and expansion 'well beyond the founding event' (Merz, Weber and Laetz 1994, 48; see also Cope 2005; Reuber and Fischer 1999).
} 
contacts within the entrepreneurial community (hence their social capital). Portrayed as ‘learning systems' (Mäkinen 2002), 'learning networks' (Tell 2000) and 'networks of practice' (Teiglan 2003), formal entrepreneurial networks function as peer groups with 'horizontal knowledge relationships' (Tell 2000, cf. also Theodorakopoulos and Figueira 2012) that go beyond instrumental concerns to extend knowledge as they allow members to engage in regular social exchange and mutual support (Bergh 2009; Ekanem and Smallbone 2007; Jack et al. 2010; Johannisson and Mønsted 1997). Network participation has been documented as triggering positive outcomes at the individual and enterprise levels (Bergh, Thorgren, and Wincent 2011; Macpherson and Holt 2007). Access to information, advice and collaborative problem-solving increases participants' ability to identify new business opportunities (Bessant, Kaplinsky, and Morris 2003; Bergh, Thorgren, and Wincent 2011; Morris, Woodworth, and Hiatt 2006; Singh et al. 1999; Tremblay and Carrier 2006; Vasilchenko and Morrish 2011) and new markets (Elfring and Hulsink 2003); access new resources (Brüderl and Preisendörfer 1998; Hoang and Antoncic 2003), and develop new business concepts and operations (McAdam et al. 2007). It can also improve entrepreneurs' capacity to elaborate international product commercialisation strategies (Vasilchenko and Morrish 2011), grow their businesses and innovate (Bosma et al. 2004; Chrisman and McMullan 2000; Lockett, Kerr, and Robinson 2008; Rogers 2004; Slotte-Kock and Coviello 2010).

Learning is 'the act or process by which behavioural change, knowledge, skills, and attitudes are acquired' (Boyd and Apps, 1980, 100-101). We conceptualise entrepreneurial learning as embedded ${ }^{2}$ into a particular social, cultural and economic context (Jack and Anderson 2002); learning is understood as the result of social

\footnotetext{
${ }^{2}$ Embeddedness designates 'the nature, depth, and extent of an individual's ties into the environment' (Jack and Anderson 2002).
} 
interactions (Cope 2005; Gibb 1997; Lave and Wenger 1991; Gherardi, Nicolini and Odella 1998; Korsgaard and Anderson 2011) and individual experiences throughout the entrepreneurial process ${ }^{3}$ (Krueger 2007). Entrepreneurial learning can be thus analysed as a phenomenon of relatedness connecting 'processes, people, and places' (Anderson, Drakopoulou Dodd and Jack (2012). This perspective contributes to what Anderson, Drakopoulou Dodd and Jack (Ibid., 962) call a 'social ontology of relatedness,' whereby the entrepreneurial process and entrepreneurs' becoming are theorised as co-produced and codetermined through social interaction.

This article aims to bring a twofold contribution to the existing network literature in the field of entrepreneurship: first, we provide empirical evidence of the progressive evolution of the design and content of a French formal entrepreneurial network from a social network to a community of practice ${ }^{4}$, thus contributing to the call for more process-based research on entrepreneurial networks (Anderson, DrakopoulouDodd and Jack 2010); second, we demonstrate that the development of the formal entrepreneurial network we studied was contingent on the members' evolving learning needs and requirements, thus contributing to a better understanding of the learning interactions underlying formal entrepreneurial networks' emergence, development and change over time (Pontus 2009; Pontus, Thorgren and Wincent, 2011). This is the first article to adopt a longitudinal process perspective on social learning in formal entrepreneurial networks in a French context.

\footnotetext{
${ }^{3}$ According to Landström(1999), Rostgaard Ervald, Klyver, and Gren Svensen (2006, 15), there are three main stages in the entrepreneurial process: firm emergence, newly established firm, and mature firm.

${ }^{4} \mathrm{~A}$ social network designates a group of individuals where members connect, communicate and coordinate mainly for socialization or instrumental reasons, 'through third parties or indirectly' (Brown and Duguid 2000, 141-142), whereas a community of practice is a group of individuals embedded in a 'social learning system because they are the social "containers" of the competencies that make up such a system' (Wenger 2000, 229).
} 
We first provide a conceptual background on the interplay of network dynamics and entrepreneurial learning. Then, we present our methodological approach and our main findings, and we discuss several theoretical and practical implications of studying formal entrepreneurial networks from a social learning process-based perspective.

\section{Conceptual background}

To study the interplay of formal networks' dynamics and entrepreneurial learning, we needed both a theory of entrepreneurial learning and a model of entrepreneurial network development. These two perspectives have rarely been combined in previous studies, because of the theoretical and methodological difficulty of studying a parallel two-level process: at the network level, the change in network design and functioning; and, at the individual and dyadic levels, the modification of learning processes and outcomes over time. Our exploratory approach combines a situated and social understanding of entrepreneurial learning with a formal network development model that builds on extant research on social learning, social networks and communities of practice.

We take an original evolutionary perspective ${ }^{5}$ to study formal networks' progression from a low to a high level of maturity, under the influence of internal and external factors. The level of participation, mutual trust, institutional support (money and expertise), along with the level of personal involvement in dyadic, sub-group and collective member interaction were stressed as the most important internal factors influencing network development by impacting the nature and strength of social ties, as well as the content and outcomes of social interactions (Jack and Anderson 2002; Johannisson 2011). The age, size and economic sector of the members' firms, the

\footnotetext{
5 There are two main process models of network development: life cycle models and evolutionary models (Verbug and Andriessen 2011). The former emphasizes networks' life from birth to death, and the latter stresses networks' progression from a low to a high level of maturity.
} 
participants' academic and professional background, and the level of geographical proximity among members have been highlighted as the most influential external factors of formal networks' development (Ibid.). Formal entrepreneurial networks start as 'a set of connections among people' with members willing to use these connections 'as a resource to solve problems, share knowledge, and make further connections' (Lebrasseur and Rochibaud 1999) and they gradually transform into a 'social and economic network,' whereby members interact to enhance their knowledge and understanding of the overall market and economic environment (Jenssen and Koenig 2002). In the first network phase, the focus of network participation is on 'learning about the business and the small business management' (Cope 2005, 380). At this stage, members get involved in developing their 'know-how' knowled ge which refers to acquiring various technical or expert skills, and their 'know-what' knowledge which consists in 'improving one's expert knowledge in relevant business areas' (Johannisson 1991, 71). In the second network phase, the focus of network participation is on 'learning about the environment and entrepreneurial networks' (Cope 2005, 380), as well as on developing one's 'know-when' knowledge which is about 'learning when to act in order to enhance the effectiveness of one's decisions and behaviours' (Johannisson 1991, 71) and one's 'know-who' knowledge which means 'learning about social structure and power relationships attached to people and institutions' (Ibid.). Once established and consolidated, mature formal entrepreneurial networks may become 'inter-organizational communities of practice' (Moingeon et al. 2006; cf. also Levy-Tadjine 2010). In this third network phase, the focus is on 'learning about oneself and learning about the nature and management of relationships' (Cope 2005) and on developing one's 'know-why' knowledge which consists in 'learning about values, attitudes and motivation' (Johannisson 1991). 
The notion of community of practice is the central construct of situated learning theories (Scarbrough et al. 2004; Wenger et al. 2002) emphasising the development of professional identity as a phenomenon occurring on the basis of participation in 'a system of situated practices' (Gherardi et al. 1998, 276; cf. also McDermott 1999; Hindle 2010; Wenger 1998). Practice scholars such as Schatzki et al. (2001, 2) understand practice as 'embodied, materially mediated arrays of human activity organized around shared practical understanding.' Within a 'social learning system' (Wenger 2000), individuals learn from doing (Rae 2000) as they reflect collectively on their practices (Cope 2003; Jack and Anderson 1999). Formal entrepreneurial networks are therefore socialisation systems designed to create favourable social interaction conditions for helping entrepreneurs to become better practitioners (Kakavelakis 2010). This learning-in-context approach highlights the idea that entrepreneurial learning occurring in a mature network context is about sharing a common repertoire and resources ('routines, vocabulary, stories, symbols, artefacts and heroes' cf. Verburg and Andriessen 2011, 37) that constitutes a basis for learning (Thompson 2005). In communities of practice (Lave and Wenger 1991), social learning, meaning negotiation and professional identity are thus all components of 'the same participative act or practice' (Thomson 2005, 153), with members' 'identity and knowledgeable practice jointly developing through interactions with a specific domain or activity' (Thorpe et al. 2005, 275). As Bender $(1982,7)$ noticed, there is a 'we-ness' in a community of practice (cf. also Cohendet, Creplet and Dupouët 2003: Dupouët, Yildizoglu, and Cohendet 2003).

However, social networks and communities of practice are neither opposite nor separate social structures but rather two 'aspects of the social fabric of learning' (Wenger, Trayner, and de Laat 2011, 10). 


\section{Research design and methodology}

Jack et al. $(2010,316)$ called for more empirical research on network change in terms of structural modifications and network dynamics. Evidence exists that networks fluctuate and change over time (Larson and Starr 1993; Wincent, Thorgren and Anokhin 2012).) that is 'shift and adapt to fit the needs of its participants' as an 'organic structure' (Jack et al. 2010, 316). Inside entrepreneurial networks, relationships evolve and ties are activated according to entrepreneurs' needs in terms of knowledge, skills and business contacts (Anderson and Jack 2002). Longitudinal approaches are thus necessary to identify and characterise ‘developmental patterns' (Hoang and Antoncic 2003, 180).

From a methodological standpoint, research on network change (Jack et al. 2008) uses the network as a level of analysis and aims to answer questions such as in what ways, and for what reasons, do networks change?' (Jack et al. 2010, 318). Our intention was to address these issues through longitudinal research conducted in a French formal entrepreneurial network that we studied over a period of four years (2005-2009). Previously acknowledged as particularly useful for exploring 'how and why questions' (Bergh, Thorgren, and Wincent 2011; Y in 2003) and for investigating the dynamics present within particular settings, case studies are empirical inquiries investigating 'a contemporary phenomenon within its real-life context' (Yin 2003, 13). Such studies are frequently used in network research (Eisenhardt 1989; Steier and Greenwood 1999).

We developed a two-level mixed methods case study design to answer our research question: how did a formal entrepreneurial network moved from a social network to a community of practice? To answer this question, we formulated two subquestions: 1) how did a formal entrepreneurial network evolved over time according to the modification of the participants' learning requirements? ; 2) how the learning 
processes and outcomes changed over time according to the network design and content evolution?

Mixed methods consist in 'the collection, analysis, and integration of quantitative and qualitative data in a single or multiphase study' (Hanson et al. 2005). The reason for choosing a mixed methods design is that we needed both qualitative and quantitative methods to study the co-evolving dynamics of network development and entrepreneurial learning (Jack 2010). The mixed methods design allows researchers to 'answer questions that cannot be answered by qualitative or quantitative approaches alone' (Creswell and Plano Clark 2006, 9). To answer our first sub-question, we needed qualitative methods, which are best suited to addressing 'how' questions (Jack and Anderson 2002). In addition to these methods, which are aimed at understanding rather than measuring a phenomenon (Oinas 1999), we used quantitative methods to evaluate changes in the network design and content. To answer our second sub-question, we needed qualitative methods to understand the interplay of network participation and learning processes and outcomes. Our research design thus comprised both quantitative and qualitative data collection and analysis.

\subsection{Data collection}

\subsubsection{The context of the study}

We studied the Entrepreneurs' Club of the Paris Chamber of Commerce from October 2005 to April 2009. ${ }^{6}$ The institutional mission of the network was that of sustaining entrepreneurial activity in the Paris region by focusing on developing a favourable learning environment for entrepreneurs willing to share their experiences and ideas

\footnotetext{
${ }^{6}$ In April 2009, 75 entrepreneurs were actively involved in the Club's meetings. We decided to stop our field research in April 2009, when the network manager quit the Club to become project manager for entrepreneurship education and training in a Parisian business school.
} 
related to their activity. A business support professional was recruited to set up the network coordination by managing network subscription and organising network activities (business meetings, round tables, theme-oriented lectures with external expert interventions, and social events). The network manager was also in charge of coordinating internal and external communication through electronic newsletters, website, media and public presentations such as business conferences. At the time of the study, two of the co-authors attended network meetings over a period of four years, beginning with the launching of the Club. They were granted this access because they worked in one of the business schools of the Paris Chamber of Commerce.

During its first months of existence, the Entrepreneurs' Club comprised 10 entrepreneurs. In four years, a total of 121 entrepreneurs paid the subscription fee for at least one year of membership. ${ }^{7}$ The network attracted mainly founders of SME service companies $(92 \%)$. The majority of members were men $(60 \%)$, running emerging firms ${ }^{8}$ $(69 \%)$ and early-development firms ${ }^{9}(19 \%)$. A small number of participants (12\%) were founders and/or managers of established and mature firms (more than eight years old). Only $12 \%$ of the firms had more than ten employees, the majority of them had between one and nine employees. The age distribution indicates that at the beginning of the network most of the members were 40 to 50 years old, whereas in 2008 and 2009 younger entrepreneurs, between 30 and 40 years old, took a strong interest in the network's activities. In April 2009, the majority of the members were 30 to 40 years old (40\%) followed by members between 40 and 50 years old $(30.67 \%)$. Only a minority were older than 50 years $(12 \%)$ or younger than 30 years $(17.33 \%)$.

\footnotetext{
7 The membership subscription was an annual fee of $€ 400$ ( $€ 150$ when the business had been founded fewer than 3 years prior, and $€ 300$ for me mbership renewal or co-optation).

${ }^{8}$ Emerg ing firms are here characterised as being less than 2 years old, cf. Hite 2005.

${ }^{9}$ Early-development firms are here characterised as being between 3 and 7 years old, cf. Gianecchini and Gubita 2012.
} 


\subsubsection{Data collection methods}

We collected a rich amount of qualitative and quantitative information to study the interplay of learning and networking throughout the Club's development (see Table 1).

The major source of data collection was participant observation ${ }^{10}$; at least one of the authors took part in the Club's various networking activities during the four-year field research. This allowed us to personally meet all the 121 network members, and to observe their relationships' evolution both in terms of social interaction patterns and in terms of information exchange content. Information about the members and their enterprises was collected through the members' records that each new member had to fill in when he/she joined the Club. Attending member induction meetings provided us with information about the members' motivations for joining the network, and their expectations in terms of learning from others' experience. Information about the learning processes and outcomes was mainly collected during business breakfasts and dinners we attended and by participating in 48 reflection groups from 2006 to 2009. Our involvement in more informal networking activities, such as business breakfasts and dinners, was informative concerning the progressive modification of the network ambiance in that it allowed us to notice that the increase in interpersonal trust among participants nurtured their willingness to be more honest and authentic in their mutual interactions.

Meeting attendance and participation in informal networking activities was an opportunity to discuss with members to gain insight into their own accounts of their networking experience. While attending these networking events, we asked participants about their involvement in network activities, the quality of their relationships with

\footnotetext{
${ }^{10}$ According to Jack et al. (2010), participant observation is particularly relevant for analysing the content and processes of network interactions.
} 
other members, their learning needs related to business development, and their motivation to interact within the network. In 2007, we also started to ask members participating in informal network gatherings about their learning experience within the network. We did not use digital-recording equipment because we wanted to avoid inhibiting effects; we thus opted to take extensive notes throughout the conversations by using the 'learning episode technique' that allows researchers to link learning antecedents (such as network participation and interaction) with perceived learning outcomes (such as knowledge and skills development, access to information and contacts, etc.). ${ }^{11}$ This technique was used in network learning research by Knight and Pye (2005), and by Theodorakopoulos and Figueira (2012). Our aim was to understand how learning issues evolved over time, where and how learning between members had occurred, and what was learned from the point of view of participants themselves. Regular meeting attendance permitted us to build a representation of the network evolution in terms of the interplay between group interaction and mutual learning. Participant observation also played a major role in the identification and analysis of the key moments, activities and points of focus around which a learning community developed over time. Participant observation was thus a precious tool that helped us explore the temporal and contextual dimensions of the relational embeddedness of entrepreneurial learning in the Entrepreneurs' Club.

From 2005 to 2009, we conducted 10 semi-directed interviews with the network manager to gather information about the network mission and objectives, and the

\footnotetext{
${ }^{11}$ During these conversations with network members, we asked them additional questions about network interaction and learning: how network relationships influenced the processes of information exchange and learning within the Entrepreneurs' Club, what they preferred to discuss with other members, what kind of information they have provided to advise or help other participants deal with business challenges or difficulties, and what information and advice provided by other members they used to improve their business activity. We also asked them about their relationships with other members, if they met other members outside the official network activities, and if they noted some improvements and/or difficulties in the evolution of the network dyna mics.
} 
strategy he followed when he decided to launch new networking activities. We also sought to identify his perception of the network evolution in terms of design (quality and quantity of relationships among participants; the emergence of sub-groups) and learning processes (the modification of the learning requirements of the participants over time and their involvement in the Club's networking activities).

In 2007, we conducted a member survey to collect data about participants' satisfaction with the network activities. This allowed us to evaluate the perceived benefits and effectiveness of the Entrepreneurs' Club. Twenty-two subscribed members (response rate of $30 \%$ ) completed the online questionnaire (7 open-ended questions and 13 closed-ended questions). The survey permitted us to identify the learning requirements of the Club's members and to compare them with the learning needs they expressed at network entry. Additional insight about members' expectations, difficulties, business successes, and network learning outcomes was collected through systematic access to the electronic correspondence between the network manager and the participants. To study the evolution of network participation, we collected the attendance sheets and minutes of all the network meetings.

To get more input about the network learning contents and objectives, we collected various sources of written materials generated by the network manager, such as 91 e-newsletters, 62 media or public presentations of the network activity, the Club's extranet and Internet site, along with the written records of 18 community of practice meetings designed for business support professionals of the Chamber of Commerce where the network manager was actively involved since its launching in 2007 . We also gathered external documents such as nine press releases of the Chamber of Commerce related to the Entrepreneurs' Club. 


\subsection{Data analysis}

Following Yin's (1992) recommendations, we built a chronological and comprehensive Excel database of both qualitative and quantitative data to facilitate synthesis and internal comparison. Additionally, we used NVivo software to code and summarise interviews and network document information, and to identify emerging themes and patterns. We then followed a two-step data analysis procedure aimed at building a processual representation of the network design and content evolution with a focus on how the members' learning needs, processes and outcomes changed over time.

First, we analysed data from interviews, participant observation, network documents, and electronic correspondence to identify the major phases of the Club's evolution. We used three main categories of indicators to categorise information regarding network evolution based on Wenger (1998, 125-126): social interaction indicators (level of participation, frequency of face-to-face meetings among members, trust level between participants, perceived quality of relationships with other members, engaging in doing things together, informal conversation, mutual help), boundary object indicators (use of extranet, use of Club's website tools, reading of the electronic newsletter, knowledge of the Club's offer in terms of networking activities, coherency and convergence of points of focus during the Club's meetings, emergence of inside jokes, jargon and shortcuts among members), and shared identity indicators (pride in being a Club member, knowledge about other members' background and expertise, similar discourse about the network's mission and values among members, connecting 
other members with personal business contacts, launching of business projects with other members).

We then identified and classified the information on the learning processes and outcomes of the Entrepreneurs' Club to identify changes according to the three phases of network development previously identified. To organise verbal data into categories of learning processes and outcomes, we used the indicators defined by St-Jean and Audet (2012). We thus classified the network learning processes according to six categories of indicators: 1/ knowledge sharing during meetings, 2/ explanation, advice and guidance among members, 3/ questioning, listening and providing feedback, 4/ role modelling, mutual inspiration and/or imitation among members, 5/ encouragement, providing emotional support, and 6/ working together, developing common projects. We classified learning outcomes into three categories (cf. Ibid.): 1/ cognitive outcomes (knowledge about cognitive strategies, management, market, customers, etc.), 2/ skillbased outcomes (acquisition or development of know-how related to one's business), and 3/ affective outcomes (modifications in members' motivations, goal-setting strategies, and personal attitudes related to one's business).

When analysing and interpreting findings, we triangulated data over our multiple sources to mitigate bias. The articulation of data extracted from participant observation, interviews, questionnaires and document analysis facilitated triangulation, which strengthened the internal validity of our case study (Eisenhardt 1989; Yin 2003).

\section{Findings}

Our findings indicate that the design and content of the Entrepreneurs' Club evolved from a social network to a social and economic network, then to a community of practice to better adapt to the learning requirements of network members. In parallel, 
the learning processes and outcomes were influenced by changes in network dynamics from the initial formation phase to network maturity.

\subsection{The evolution of the Entrepreneurs' Club according to the changes in participants' learning needs over time}

\subsubsection{Phase 1 - Formation (2005-2006): Social network stage}

The Entrepreneurs' Club was launched in October 2005. The main objective of the Club as stated during the first press conference was to "fight against the solitude of the entrepreneur' by facilitating peer business contacts and mutual learning:

\footnotetext{
'At the Club's launching, the steering committee of the Paris Chamber of Commerce stressed that our objective was to build a sustainable community of entrepreneurs eager to learn and develop their activities to enhance the attractiveness of the Paris area' (network manager, interview).
}

Initially, the network mainly functioned as a social gathering of entrepreneurs learning to know each other better, progressively trusting each other, and starting to share their thoughts and doubts about management, business development, and the difficulty of having a 'normal' family life during the first enterprise years, which confirms the findings of Brown and Duguid (2002). For some entrepreneurs, the Club was a means of fighting the isolation of the small-business owner-manager through 'meeting with peers and discussing stressful and demanding business issues' (entrepreneur, electronic correspondence). When questioned about their learning expectations, the first members mentioned their hope of meeting similar people, facing similar challenges and learning together how to deal with them more effectively. Affective learning requirements in terms of seeking encouragement, support and feedback were as important in the participants' discourse as cognitive learning 
expectations in terms of broadening one's perspective about economy, politics, and business. At this phase, the only opportunities they had to meet were face-to-face network activities, with boundary group objects (website, extranet, electronic newspaper) emerging progressively during 2006.

The initial Club gatherings ${ }^{12}$ involved business breakfasts on marketing, strategy, law, finance, $\mathrm{HR}$, and product commercialisation topics, where members and the manager discussed challenges and solutions, together with other invited entrepreneurs and experts. At the beginning of 2006, 15 to 20 entrepreneurs attended these meetings, while at the end of the year there were over 30 attendees. Business breakfasts and dinners were described by participants as good occasions for socialisation, allowing members to know each other better. Members did not know each other before entering the Club, but, once involved, the most active members attended meetings twice a month, and met other members once or twice a month outside the 'official gatherings' (entrepreneur, electronic correspondence):

\begin{abstract}
'I was so excited about meeting other entrepreneurs running young firms, just to talk together and relax... Sometimes is hard not to have anybody in the company to speak to about our difficulties and fears! Business dinners and breakfasts were a nice occasion to see each other, and learn that other members were facing very similar challenges...' (entrepreneur, business dinner).

'After business breakfasts, we usually stayed together to discuss in a cafe' (entrepreneur, electronic correspondence).
\end{abstract}

A weekly e-newsletter written by the network manager was launched in March 2006, with information about new members, past and future events, and members' news about support and resource needs and offers. In April 2006, a new activity was

\footnotetext{
12 In January 2006, the Club brought together the first 10 founding members, while at the end of the year there were 40 network participants.
} 
launched, a best practices meeting where, at the initiative of a member with longestablished experience in a specific domain (such as vocational learning, tax and insurance, or extranet), participants were invited to discuss business difficulties and share potential solutions in a friendly environment. As Gongla and Rizzuto (2001, 847848) observed 'connection is the fundamental function' of the network at this stage ${ }^{13}$, with a small number of entrepreneurs forming the 'nucleus' of the Club socialising together, starting to communicate and form relationships. Jack et al. (2010, 324) characterise this formation phase as 'functionalist,' with the network starting to function on a regular basis in three main meeting formats (business breakfasts, business dinners, and best practices meetings) allowing members to engage in initial interactions and to gradually develop their contacts within the network.

The learning processes that largely characterised this first phase were knowledge sharing during meetings, along with questioning, listening and providing feedback. As members began meeting regularly, some emotional support was also expressed by members, as predicted by St-Jean and Audet (2012). In terms of learning outcomes, members acknowledged cognitive outcomes, such as improvements in market and customer knowledge, or a broader understanding of the French economy in terms of financial issues and legal requirements. Affective outcomes also surfaced, such as the 'feeling of being less isolated' and the 'feeling of being understood by people facing similar problems' (entrepreneurs, electronic correspondence). These outcomes indicate that the network reached the first value creation cycle (cf. Wenger, Trayner and de Laat 2011,38), which consists in immediate value creation through collective activities and

\footnotetext{
13 Gongla and Rizzuto (2001) elaborated an evolutionary model with networks first providing members with access to one another (initial formation phase), then fostering me mbers' collective learning (second phase) while making shared knowledge available for an external audience (third 'active phase'); at the fourth 'adaptive phase' members build new solutions, methods and process es together.
} 
interactions: 'meeting someone, getting an address, connecting, asking a question of the network, passing a piece of information along, or giving input.'

'At the end of 2006, we achieved our quantitative and qualitative objectives. During the year, we adjusted our internal and external communication and the provision of services according to the needs expressed by the members. At first rather passive participants, they wanted to know more about the network's offer in terms of activities and contacts. By June 2006, more of them became active participants, and they clearly started to state their wishes and needs' (network manager).

To start building a learning community, however, it is not sufficient to simply gather entrepreneurs and invite them to speak to one another about their work. There is a need for members to identify with each other, to recognise that they are similar 'in something that they value' (Gongla and Rizzuto 2001, 849; cf. also Cohendet, Creplet and Dupouët 2003). This mutual recognition reinforces the foundations of a potential entrepreneurial community. At the end of 2006, the Club increasingly shifted towards a social and economic network, with participants building stronger relationships, getting more involved in sharing and discussing specific entrepreneurial and managerial issues, starting to give one another help and advice, and taking the initiative to form working subgroups to jointly develop new business solutions. We viewed this as a sign that the network had moved to its second development phase:

'After the first Best practices meeting on vocational learning financing issues, together with six other entrepreneurs, we decided to form a small group to put together our training budgets and thus to buy a personalised collective training solution, delivered by a prestigious business school, on the topic of marketing, communication and development. We called ourselves the Oxygen group' (entrepreneur, electronic correspondence). 
4.1.2. Phase 2 - Development and reconfiguration (January-November 2007): social and economic network stage

In 2007, the Club evolved both in terms of relational dynamics among members and of the learning expectations explicitly articulated by the participants in the online survey conducted in April 2007. Members reported being satisfied with the overall functioning of the network, and the meetings' content and regularity. They also made several suggestions about further improvements:

'I would like to have more opportunities to exchange ideas among us, without any other formal expert presentation, just stay together and discuss our own enterprises and current issues'

'I think it would be great to divide the network into small sub-groups according to the enterprise size and age, to be able to discuss specific issues and produce know ledge together'

'I would like to attend more cocktail parties and speed meetings open to external entrepreneurs, from other clubs or networks of our region' (entrepreneurs, online survey).

Members' expressed both a need for greater network 'intimacy' and 'identity enhancement' and for more 'network openness' and 'contact' with external stakeholders, which indicated an increase in relational embeddedness that entailed integrating a 'business' dimension in the initial social network dynamics. As emphasised by Hite (2005, 135-136), relational embeddedness within entrepreneurial networks is both additive and recursive in that relationships involve both a social and a business dimension documented as beneficial for entrepreneurs of emerging and earlydevelopment firms, such as the majority of the Club's members. The evolution of relational embeddedness may also favour relational exchange and resource acquisition for both members and external entrepreneurs (Zaheer and Venkataraman 1995). 
The members' electronic correspondence with the network manager indicates that they were rather satisfied with the diversity and richness of business contacts provided by the membership base. However, in 2007 some of them called for a broader network foundation, which is why inter-club meetings were formalised with other entrepreneurs' clubs in the Paris area. To answer the need for increased external participation, the business breakfast format was also modified to meet the group's requirements: the meeting started with a talk by an expert, followed by a discussion and a debate with members. ${ }^{14}$ In response to members' requests for increased regular contact with other entrepreneurial networks, business breakfasts integrated an inter-club format by the end of April. ${ }^{15}$ These developments are indicators of a network design and content that evolved according to the members' affective, cognitive and learning needs. Discussions with internal and external entrepreneurs became more focused on business issues: how to find a supplier, how to organise a prospecting campaign among future mothers, how to find solid investors, how to manage an intercultural team, etc. The perceived quality of relationships within the network increased, as did the amount of informal conversation aimed at mutually providing help and advice. We also noticed the emergence of inside jokes and a growing pride in being a Club member. As a consequence, members became more confident in each other's ideas and more open to sharing thoughts and doubts about the management of their enterprise and their personal difficulties in dealing with stress and pressure. This is in line with network research indicating that trust among members is crucial to facilitate knowledge sharing (Bergh,

\footnotetext{
${ }^{14}$ Fifteen to thirty participants attended these meetings on a regular basis.

15 The first inter-club business breakfast organised with another network in the Paris area on the topic of 'E-reputation and e-commerce' brought together 80 participants of both clubs. In July, 90 members and non-members attended the annual business dinner organised by the club on the topic of 'Sports and Entrepreneurship.' A mongst the Club's events of 2007, the highest number of participants registered for inter-club business breakfasts (25 to 80 participants) and dinners ( 80 to 400 ).
} 
Thorgren, and Wincent 2011; De Wever, Martens, and Vandenbempt 2005; Harmaakorpi and Melkas 2005).

At this stage, the initial Club's members, as a group, started to define the nature of the network and how it would function. Members had their own representative in the Club's board and they directly influenced the meetings' format and content, as well as the network's growth in terms of recruitment. In other words, members were beginning to co-create with the network manager a network structure and processes allowing participants to interact and learn together. Jenssen and Koenig (2002) characterise this phase as a 'social and economic network', while Gongla and Rizzuto (2001, 847) describe it as a 'context creation and memory' phase, with nucleus members increasingly involved in building the network functioning and common vocabulary, creating roles and norms, then sharing them with new entrants and thus generating a shared history. This is the moment when members started thinking about what it meant to belong to the same group or community (Ibid., 850). A sense of belonging started to surface in their discourse by the end of 2007 :

'Little by little, I realized that the central role that I played at the beginning is actually disappearing, giving way to many parallel interactions between members outside the official activities of the network, which I discovered after the fact, and often by chance' (network manager, interview).

'In addition to being an entrepreneur, I am also a musician in a classical music ensemble. I regularly give concerts to which I invite all the network members.' (entrepreneur, business dinner)

'When I had to modify my communication plan, I did not hesitate to call one of the members of the network. I knew he was competent in his field and that the pricing would be fair. I trusted him.'

'I was looking for a lawyer to draft my shareholder agreement and I asked the members of the club to recommend me someone.' 
'I decided to pursue an external growth strategy, so I discussed it with network members asking them to direct me to any information and contacts they may think relevant' (entrepreneurs, electronic correspondence).

Some entrepreneurs expressed the intention to share resources with other members without expecting or asking for something in exchange:

'When I walked into my new office, near Paris, I had a much larger area than I needed for my business. I spoke about it to the network manager and asked him to relay the information and invite members to come share my office. One member accepted my proposal-I asked him to pay me half the market price' (entrepreneur, electronic correspondence).

Members acknowledged the network's role in helping them connect with an important number of inside and outside entrepreneurs, as well as with consultants, academics and policy makers in the Paris area. For instance, members had the opportunity to participate in public debates on important issues, such as urban development of Paris, with policy makers, sociologists and architects, at the initiative of the Chamber of Commerce. Peripheral participants provided a range of business expertise that members mobilised for their business.

After network meetings, the network manager systematically asked participants to provide feedback on learning outcomes. At the end of best practices meetings, participants individually presented a short action plan concerning the application of the information and knowledge they acquired at the meeting in their own company. Changes in knowledge, perspective and reputation were acknowled ged by members on various occasions, which indicates that the network reached the second value creation cycle as conceptualised by Wenger, Trayner and de Laat (2011). This second cycle consists in progressively acquiring knowledge capital through active network participation (human capital - increased skills, knowledge, self-confidence and sense of 
professional identity, social capital - increased reputation and access to business relationships and connections endowed with trust, resources - documents, tools, procedures, reputational capital - collective network recognition, and learning capital experience transfer to other contexts). Members credited the network with enhancing their practical and strategic understanding of business issues. Moreover, they recognised that the network was helpful in terms of providing them with emotional support and self-confidence. For instance, a young entrepreneur found commercial prospecting difficult to implement because of his shyness. The support and advice from the Club's members helped him prospect more effectively.

To sum up, in terms of typical learning processes occurring during this network phase, we identified a significant increase in the amount of explanation, advice and guidance among members, more encouragement and emotional support within the network, along with learning processes that already started to surface during the previous formation phase (knowledge sharing, questioning, listening and providing feedback). The most significant learning outcomes at this stage were mainly cognitive, with enhanced knowledge about business strategy and management, and a rich amount of affective outcomes as members indicated that network participation was a source of inspiration that helped them to assume their managerial role differently, and sustained their efforts to better orchestrate what they call 'a family-business life equilibrium.'

To answer the need for increased business interaction and learning, in November 2007 the Club launched 'free discussion meetings' for members exclusively. We consider this the moment when the network shifted towards creating a learning 
community, completing its 'instrumental' phase (cf. Jack et al. 2010) and entering an 'altruistic' phase (Ibid.). ${ }^{16}$

\subsubsection{Phase 3 - Building a learning community (November 2007-April 2009): the} community of practice stage

The Entrepreneurs' Club increased significantly in size and complexity at the end of $2007,{ }^{17}$ with participants starting to collaborate on multiple planes to solve business issues and even to exploit opportunities together. The original network members got more involved in sharing explicit and tacit knowledge related to the functioning of the network itself, thus helping new members understand what the Club was about and how participants may contribute to build a collective knowledge base. This network phase can be characterised as both an 'engaged stage' and an 'active stage' (Gongla and Rizzuto 2001).

The best practices meetings became a major networking activity where members expressed the desire to improve their knowledge related to business development issues. Specifically, members identified two key difficulties in dealing with early-growth challenges, that of communicating effectively with stakeholders and that of acquiring new clients and markets. As a consequence, some of the best practices meetings were transformed into 'training sessions' dedicated to imparting pitch techniques applied to self-presentation contexts, with the network manager coordinating group interactions and participants sharing experiences and ideas to improve one another's oral

\footnotetext{
16 In April 2007, the network manager jointly launched with colleagues at the Paris Chamber of Commerce a 'Community of Practice' group for business support professionals in the Paris area.

${ }^{17}$ In 2008, the attendance sheets indicate a total of 285 attendees of business breakfasts, 149 attendees of best practices meetings, 310 attendees of the business dinner, 85 attendees of free discussions meetings, and 80 attendees of the annual garden party. Twenty-seven best practices meetings and three 'free discussion meetings' were organised, together with two inter-club business meetings, seven business breakfasts, an inter-club business dinner and a garden party.
} 
performance. The network meeting format and content evolved to increasingly meet the expectations of early-stage enterprises, but older members were also satisfied with discussing issues such as strategy development, which they viewed as an opportunity to play the role of 'mentor' and 'older brother' with young entrepreneurs (entrepreneurs, electronic correspondence).

At the members' request, several sub-groups were formed that functioned as communities of practice hubs: a pitch group, a small business management and HR group, a corporate communication group, a commercialisation group, and a group dedicated to development strategy. These sub-groups were organised around a core of seven to ten entrepreneurs who regularly attended meetings, demonstrated affection for one another, shared trust and values, and were willing to contribute to knowledge creation through voluntary participation:

'I am the head of the oldest company of the Entrepreneurs' Club and yet I did not hesitate a minute to register for the pitch subgroup as I felt that despite my 20 years of experience I never managed to introduce my company and myself briefly and convincingly enough to clients and business partners' (entrepreneur, electronic correspondence).

The Club progressively became a learning community with strong ties linking a relatively small group of members who were engaged and passionate about sharing ideas, experience and spending time together both inside and outside the Club, and a periphery of more occasional and opportunistic participants who came to meetings only when the topic was of interest or when they wanted to ask for advice and support. A third circle of individuals was formed by peripheral participants who were members in other entrepreneurial networks and regularly attended inter-club meetings. Although $20 \%$ to $30 \%$ of members admitted to rarely attending meetings, they justified their limited participation by explaining that they were particularly occupied with 
consolidating their enterprises. Some of them also admitted to being self-centred in their networking behaviour and thus selecting commitments based on the meeting topic. Those who attended meetings on a regular basis were both early-stage entrepreneurs and more established entrepreneurs who appreciated the diversity of discussion topics, and recognised that the Club was also an 'emotional support in difficult times' (entrepreneur, electronic correspondence).

As stressed by Gongla and Rizzuto (2001, 853) 'collaboration becomes a fundamental function at the active stage.' Members became aware of one another's expertise and turned to the community when faced with business difficulties. Jack and Anderson $(2002,203)$ contend that this network development stage involves more than just 'becoming informed' and 'becoming known' issues (social network): it allows members to do more than just 'tap into external resources' or 'knowledge held by others' (instrumental network, corresponding to the social and economic phase). Creating a learning community helped the members 'find new business' opportunities, 'maintain existing businesses' and even, for some participants, 'make friends' (Ibid.).

Members acknowledged the use and implementation of advice, solutions and insights to innovate and enhance their current managerial practices. For instance, an entrepreneur who tried to recruit his first employee for several months without much success finally found a good candidate in just 15 days after a free discussion meeting where he shared his problem with other participants. Another member decided to modify her commercial strategy following a business breakfast meeting; participants advised her to rely more heavily on her client database to increase the firm's selling performance. Moreover, interactions among members triggered concrete business collaborations, such as co-branding between two companies in the field of corporate communication, and joint participation in professional trade shows. These findings 
indicate that the network reached the third value creation cycle (Wenger, Trayner and de Laat 2011), which consists in changes in practice: applying knowledge to change procedures, implementing new ideas and approaches.

The key learning processes occurring at this network stage were role modelling and working together with other members. Of course, members made extensive use of all the other learning processes identified in the two previous network phases, such as knowledge sharing during meetings, explanation, advice and guidance, questioning, listening and providing feedback, encouragement and emotional support. Shared entrepreneurial practice became a source of coherence for the community of the Entrepreneurs' Club through a process of mutual engagement (social interaction leading to group relationships and norms), the emergence of a sense of joint enterprise (a common understanding of the group's mission and values), and, finally, the generation of a shared repertoire of resources (routines, artefacts, and language). The Club's mission and functioning were increasingly negotiated through a process of participation and reification (Wenger 1998, 55), with reification consisting in the process of giving form to experience by producing boundary objects such as stories, concepts, symbols 'that reify something of that practice in a congealed form' (Ibid., 59).

In May 2008, the Entrepreneurs' Club became one of the 12 founders of the national inter-club network 'France Entrepreneurs.' The objective of this association was to provide more business contact opportunities and improve access to information. By late 2008, there were 95 Club members and 
'they decided to add a clause in the Entrepreneurs' Club membership charter about limiting the number of members to 120 and conditioning membership renewal on active participation' (network manager, interview) ${ }^{18}$.

We perceived this as a strong indicator of emergence of a shared in-group identity. One of the key assumptions of the theory of community of practice is that learning is not only an individual cognitive process but also the result of a social trajectory within a group. According to social identity theory (Tajfel and Turner 2004), when in-group identity becomes salient, participants express public identification with the group and greater pride in being group members, along with the desire to distinguish themselves from those who are not members of their group.

Insert Table 2 about here

\section{Discussion}

Previous research in entrepreneurship focussed on entrepreneurial networks and their development from a social capital perspective, along with an interest in studying the progressive extension of new venture networks, from the start-up phase, to the maturity stage with a social network approach (Birley 1985; Dubini and Aldrich 1991; Hite and Hesterly 2001; Hite 2005; Hoang and Antoncic 2003; Staber and Aldrich 1995). These studies generated several consistent findings such as evidence of network change (Jack, Drakopoulou Dodd and Anderson 2008) in terms of modification of the quality and quantity of relational ties over time (Larson and Starr 1993), and an increased

\footnotetext{
18 The network size gradually evolved from 10 members at the beginning of 2006 to 95 members at the end of 2008, when members decided to limit the number of adherents to 120 so as to secure the group's ability to allow active participation of potentially all participants. Membership progression was strong in 2007 when the number of adherents almost doubled from 40 to 74 me mbers.
} 
recognition of the major role of cognitive and affective trust in entrepreneurial network development (Hite 2005; Larson 1992). A much less studied issue was that of networks of entrepreneurs, especially formal entrepreneurial networks (Parker 2008). This article contributes to filling this gap in the entrepreneurship literature by taking a theoretical and methodological approach that combines a social network evolutionary perspective to analyse the development of the Entrepreneurs' Club from 2005 to 2009 with a situated social learning perspective to identify the learning processes and outcomes experienced by Club members throughout the network evolution.

Our findings are consistent with the evolutionary models of network development (de Rond and Bouchikhi, 2004; Gongla and Rizzuto 2001; Parkhe, Wasserman and Ralston 2006) and the evolutionary approach of relationally embedded network ties (Hite 2005). In addition, we bring evidence of the progressive transformation of a formal entrepreneurial network into a community of practice as characterised by Wenger (1998). Building on the entrepreneurial learning literature (StJean and Audet 2012) we additionally demonstrate that formal entrepreneurial network evolution occurs concomitantly with a transformation of participants' learning processes and outcomes. In the following sections, we discuss these findings and highlight some theoretical and practical implications of our research.

\subsection{Theoretical implications for future research}

The first triggers of the Club's development were the members' learning needs and requirements and the decisions taken by the network manager within a particular institutional context, that of the Paris Chamber of Commerce. The network's activities, structure and functioning evolved to answer these needs. Once the network design and structure started to change owing to the pressure of the members' learning requirements, 
and once the core members' relationships became more robust in terms of mutual knowledge and trust, the learning processes occurring through the mediation of face-toface or distant network social interaction also changed. Modifications in learning processes transformed the learning outcomes acknowled ged by participants. Further, a shared identity gradually emerged because of the increase in network participation, density, learning, and collaboration. However, we may argue that this development process applies only to the core members who had participated in the network activities since the Club's foundation. In contrast, for new entrants, both network development and their personal learning and identity experiences overlapped only partially because each individual needed to undergo three phases of 'socialisation,' 'instrumentalisation' and 'altruism' at a more accelerated pace than that of the network itself (or that of the core members) to pass from the periphery to the network centre in terms of participation, knowledge and recognition. Additional research is required to better understand the moderating role of mode and time of network entry on members' learning processes and outcomes in formal entrepreneurial networks.

From a more analytical perspective, our research indicates that entrepreneurs' learning needs evolved from a search for socialisation opportunities, specifically to meet other people with similar work-related issues and comparable lifestyle, to a more instrumental orientation, when members started to look at peer relations as potential sources of information, guidance, and additional business contacts. This chronological perspective on network development should not hide the fact that the network grew rather than shifted from one stage to another, which means that the instrumental phase also comprised a strong socialisation dimension, and that the third learning community phase also involved socialisation and instrumental issues. The coexistence of socialisation and instrumental social interaction objectives generated network 
relationships and learning processes that constantly mobilised the participants' cognitions and emotions. The study of the network members' learning experience in context allowed us to understand that learning occurring in a network environment is both cognitive and affective, as stressed by St-Jean and Audent (2012). In line with Brown and Duguid (2000, 290), our findings confirmed that 'learning and emotion work together in a tandem motion.' Yet few studies have been dedicated to the exploration of the relationship between cognition and emotion in entrepreneurial learning. There is thus a need for additional research into the moderating role of emotion in the acquisition of new attitudes, beliefs and representations in an entrepreneurial network context.

Social interaction patterns evolved according to the dynamics of members' learning needs. Weak ties characterised the network formation phase, but some of these ties became stronger and the network acknowledged increased densification. This generated a dynamic network structure composed of two main categories of members: the core participants who were in the group from the beginning, and those who entered the network during the second and the third network phases. The latter were "peripheral participants' in Wenger's terms (1998), who needed to fight for increased internal recognition, trust and access to knowledge and resources. One of the key mechanisms allowing them to increase their centrality within the network was the modelling of the 'older' members' behaviour, attitudes and language (Holcomb et al. 2009). Modelling or vicarious learning (Bandura 2006) played a double role in the Club's functioning: in terms of cognitive learning, role modelling characterised the community of practice network stage, and was also a process enhancing new members' adjustment to the network's tacit norms and rules. Vicarious learning was thus both a learning process and a social interaction mechanism linking new and older network participants. 
However, to be effective, vicarious learning requires prior identification among members (Scott 2009; Wheeler, Petty and Bizer 2005; Wilson et al. 2009; Wohlford, Lochman and Barry 2004). Identification was highly facilitated because the vast majority of the participants were managers and owners of young firms, which means that they were facing similar business challenges. Further research could examine the role of various moderating variables such as the members' gender, learning orientation and perceived similarity, on the impact of vicarious learning in an entrepreneurial network context.

We identified several learning processes indicating that sharing experiences and ideas among entrepreneurs in a network context could be a trigger of both 'adaptive' and 'proactive generative learning' (Ibid.). The first is cumulative and consists in learning through personal experience, which enables entreprene urs to acquire an 'experiential stock' (Reuber and Fischer 1999) of knowledge (Minniti and Bygrave 2001) and know-how (Kim 1998). Network interactions invite entrepreneurs to build on their previous life experiences by telling the story of past entrepreneurial events and transforming experience into a narrative form. This adaptive generating learning is a source of reflexivity and critical examination for those who narrate their life events and a source of 'proactive generating learning' for those who hear their story, the latter being 'sensitized to potential critical incidents by becoming attuned to factors and circumstances that may become «critical»' (Cope 2005, 387; cf. also Cope and Watts 2000). Future research could investigate the articulation of adaptive and proactive generating learning in formal entrepreneurial networks.

This article emphasised learning as an intrinsically social process (Pavlica, Holman, and Thorpe 1998), not only in terms of occurring in certain situations and environments, but also because learning is 'an integral and inseparable aspect of social 
practice' (Lave and Wenger 1991, 31). As such, it is a process generated 'in relationships with others' (Cope 2005, 388) and 'in collaboration with others' (Holman, Pavlica, and Thorpe 1997, 143; cf. also Harrison and Leitch 2005). Future research could study the learning environments and relationships specific to the various phases of the entrepreneurial process, from pre-start-up to early development and growth (Anderson 2000). For instance, Omrane, Fayolle and Zeribi-Benslimane (2011) demonstrated that in each of the major phases of the entrepreneurial process, entrepreneurs need particular skills to secure business launching (such as information gathering and evaluation capacities and the ability to stay focused), business maintenance (such as the capacity to deal with ambiguity, paradoxes, newness, and project management skills) and development (strategic and business development skills). A situated approach to entrepreneurial learning also implies that the relationships entrepreneurs develop in formal network contexts may differ according to the various phases of the entrepreneurial process: there is empirical evidence that entrepreneurs' personal or egocentric networks evolve over time according to the particular phase of the entrepreneurial process in which they are involved (Lechner and Dowling 2003; Schutjens and Stam 2003). Finally, studying entrepreneurial learning in context requires additional research on language, given that language is a key vehicle for sharing ideas and experiences in networks, and that different communication strategies trigger different emotional, cognitive and behavioural outcomes (Radu and Redien-Collot 2013).

\subsection{Implications for entrepreneurship practice}

There are several implications of our research for public and private entrepreneurship support institutions, network managers, and entrepreneurs. Our findings may help 
support institutions better understand their role in nourishing entrepreneurial learning. Of course, launching and sustaining formal networks is a means to encourage business contact development in a particular geographical region. However, to effectively promote collective learning in network contexts, business support institutions need to invest people, time and money to carry on the efforts needed to attract new members, manage network activities, and connect the network with experts and business players from the external environment. The initial financial and organisational effort would thus be significant, and the network outcomes would be gradual rather than immediate.

Additionally, we discovered that the network managers' role has to evolve in step with the network development. In each of the network phases, managers must adapt their discourse and behaviour to the nature of the network members (older vs. recent participants) and to their learning requirements. To do so, they should be sensitive to the network evolution, so that they can initiate and pilot network activities in accordance with network changes. One of the key skills of formal network managers is thus that of being capable to adapt to the network dynamics. If difficulties arise, it could be useful for managers to participate in business support learning communities to improve their capacity to deal with learning issues.

Our findings suggest that entrepreneurs should choose to integrate formal networks that are in tune with their learning expectations, and where they could identify with other members. Once integrated into a formal network, entrepreneurs would need to adapt their behaviour according to their network status: members of a newly created network, they should be proactive to build a network functioning that best satisfies their needs. People who join an existing formal network should systematically attend meetings to accelerate their integration and their passage from the periphery to the network centre. Also, entrepreneurs should give the network manager feedback 
concerning their needs, to enable the manager to adjust the learning environment to their requirements.

\section{Conclusion}

Entrepreneurial networks have been acknowledged as a major source of social capital (Anderson and Jack 2002), learning (Politis 2005) and identity (Hindle 2010). However, we still know little about the co-evolving dynamics of learning, identity and social interaction in formal entrepreneurial networks.

This article contributes to the existing entrepreneurship literature by taking a longitudinal network approach to study the combined development of network dynamics and learning in a French formal entrepreneurial network. Building on a situated social perspective on entrepreneurial learning, we demonstrate that network learning processes and outcomes are contingent on network evolution. An additional ingredient of the interplay of network dynamics and learning over time is the progressive genesis of a shared identity among Club members, which contributed to the building of a learning community. Further research on the interplay of social network interaction and learning needs should take into account the shared identity issue, which can be conceptualised as both a potential outcome of network dynamics and a trigger of new learning processes and outcomes.

We used a single learning network, the Entrepreneurs' Club of the Paris Chamber of Commerce, to develop an understanding of the evolution from a network to a community of practice. The main limitation of our research is that findings based on a single case study cannot be generalised to other types of formal entrepreneurial networks, in other institutional and cultural contexts. More comparative research should thus be conducted at regional, national and international levels. 


\section{References}

Anderson, Alistair R, Sarah Drakopoulou Dodd, and Sarah L. Jack. "Entrepreneurship as Connecting: Some Implications for Theorising and Practice." Management Decision 50, no. 5 (2012): 958-971.

Anderson, Alistair R., Sarah Drakopoulou Dodd, and Sarah L. Jack. "Network practices and entrepreneurial growth." Scandinavian Journal of Management, 26, no. 2 (2010): 121-133.

Anderson, Alistair R., and Sarah L. Jack. "The Articulation of Social Capital in Entrepreneurial Networks: a Glue or a Lubricant?" Entrepreneurship \& Regional Development 14, no. 3 (2002): 193-210.

Anderson, Alistair R. "The Protean Entrepreneur: The Entrepreneurial Process as Fitting Self and Circumstance." Journal of Enterprising Culture 8, no. 3 (2000): 201-234.

Bandura, Albert. Psychological Modeling: Conflicting Theories. Transaction Publishers, 2006.

Bender, Thomas. Community and Social Change in America. John Hopkins University Press, 1982.

Bergh, Pontus. Learning Among Entrepreneurs in Formal Networks: Outcomes, Processes and Beyond. Umeå School of Business, Umeå University, 2009.

Bergh, Pontus, Sara Thorgren, and Joakim Wincent. "Entrepreneurs Learning Together: The Importance of Building Trust for Learning and Exploiting Business Opportunities.” International Entrepreneurship and Management Journal 7, no. 1 (2011): 17-37.

Bessant, John, Raphael Kaplinsky, and Mike Morris. "Developing Capability through Learning Networks." International Journal of Technology Management \& Sustainable Development 2, no. 1 (2003): 19-38.

Birley, Susan. "The role of networks in the entrepreneurial process." Journal of Business Venturing 1 (1985):107-117.

Bosma, Niels, Mirjam van Praag, Roy Thurik, and Gerrit de Wit. "The Value of Human and Social Capital Investments for the Business Performance of Startups." Small Business Economics 23, no. 3 (October 2004): 227-236.

Boyd, Robert Dean, Jerold W Apps, and others. Redefining the Discipline of Adult Education. Jossey-Bass, 1980.

Brown, John Seely, and Paul Duguid. The Social Life of Information. Boston: Harvard Business School Press, 2000.

Brüderl, J., and P. Preisendörfer. "Network Support and the Success of Newly Founded Business." Small Business Economics 10, no. 3 (1998): 213-225.

Chrisman, James J, and W Ed McMullan. "A Preliminary Asse ssment of Outsider Assistance as a Knowled ge Resource: The Longer-term Impact of New Venture Counseling." Entrepreneurship Theory and Practice 24, no. 3 (2000): 37-54.

Cohendet, Patrick, Frédéric Créplet, and Olivier Dupouët. "Innovation Organisationnelle, Communautés de Pratique et Communautés Épistémiques: Le Cas de Linux." Revue Française de Gestion 5 (2003): 99-121.

Cohendet, Patrick, and Patrick Llerena. "He Knowledge-Based Entrepreneur: The Need for a Relevant Theory of the Firm." In Knowledge-intensive Entrepreneurship and Innovation Systems : Evidence from Europe, by Franco Malerba. Routledge, 2010.

Cope, Jason. "Toward a Dynamic Learning Perspective of Entrepreneurship." Entrepreneurship Theory and Practice 29, no. 4 (July 2005): 373-397. 
Cope, Jason. "Entrepreneurial Learning and Critical Reflection Discontinuous Events as Triggers for 'Higher-level' Learning." Management Learning 34, no. 4 (2003): 429-450.

Cope, Jason, and Gerald Watts. "Learning by Doing-an Exploration of Experience, Critical Incidents and Reflection in Entrepreneurial Learning." International Journal of Entrepreneurial Behaviour \& Research 6, no. 3 (2000): 104-124.

Creswell, John W, and Vicki L Plano Clark. Designing and Conducting Mixed Methods Research. Sage, 2011.

De Rond, Mark, and Hamid Bouchikhi. "On the dialectics of strategic alliances." Organization Science, 15, no. 1, (2004): 56-69.

De Wever, Sigrid, Rudy Martens, and Koen Vandenbempt. "The Impact of Trust on Strategic Resource Acquisition through Interorganizational Networks: Towards a Conceptual Model." Human Relations 58, no. 12 (2005): 1523-1543.

Dubini, Paola, and Howard Aldrich. "Personal and extended networks are central to the entrepreneurial process." Journal of Business Venturing 6, (1991):305-313.

Dupouët, Olivier, Murat Yildizoglu, and Patrick Cohendet. "Morphogenèse de Communautés de Pratique.” Revue D’économie Industrielle 103, no. 1 (2003): 91-110.

Eisenhardt, Kathleen M. "Building Theories from Case Study Research." Academy of Management Review (1989): 532-550.

Ekanem, Ignatius, and David Smallbone. "Learning in Small Manufacturing Firms The Case of Investment Decision-making Behaviour." International Small Business Journal 25, no. 2 (2007): 107-129.

Elfring, Tom, and Willem Hulsink. "Networks in Entrepreneurship: The Case of Hightechnology Firms." Small Business Economics 21, no. 4 (2003): 409-422.

Gherardi, S., D. Nicolini, and F. Odella. "Toward a Social Understanding of How People Learn in Organizations: The Notion of Situated Curriculum." Management Learning 29, no. 3 (September 1, 1998): 273-297.

Gianecchini, Martina, and Paolo Gubitta. "Entrepreneurs' Knowledge and Network: What Matters the Most? The Case of Knowledge-Intensive Firms." In Academy of Management Proceedings, 2012: 1-1.

Gibb, Allan A. 'Small Firms' Training and Competitiveness. Building Upon the Small Business as a Learning Organisation.” International Small Business Journal 15, no. 3 (1997): 13-29.

Gongla, Patricia, and Christine R. Rizzuto. "Evolving Communities of Practice: IBM Global Services Experience.” IBM Systems Journal 40, no. 4 (2001): 842-862.

Hanson, William E, John W Creswell, Vicki L Plano Clark, Kelly S Petska, and J David Creswell. "Mixed Methods Research Designs in Counseling Psychology." Journal of Counseling Psychology 52, no. 2 (2005): 224.

Harmaakorpi, Vesa, and Helinä Melkas. "Knowledge Management in Regional Innovation Networks: The Case of Lahti, Finland 1." European Planning Studies 13, no. 5 (2005): 641-659.

Harrison, Richard T., and Claire M. Leitch. "Entrepreneurial Learning: Researching the Interface Between Learning and the Entrepreneurial Context." Entrepreneurship Theory and Practice 29, no. 4 (July 2005): 351-371.

Hindle, Kevin. "How Community Context Affects Entrepreneurial Process: A Diagnostic Framework." Entrepreneurship and Regional Development 22, no. 7-8 (2010): 599-647.

Hite, Julie M. "Evolutionary Processes and Paths of Relationally Embedded Network Ties in Emerging Entrepreneurial Firms." Entrepreneurship Theory and Practice 
29, no. 1 (2005): 113-144.

Hite, Julie M, and William S Hesterly. "The Evolution of Firm Networks: From Emergence to Early Growth of the Firm." Strategic Management Journal 22, no. 3 (2001): 275-286.

Hoang, H., and B. Antoncic. 'Network-based Research in Entrepreneurship: A Critical Review.” Journal of Business Venturing 18, no. 2 (2003): 165-187.

Holcomb, Tim R, R Duane Ireland, R Michael Holmes Jr, and Michael A Hitt. "Architecture of Entrepreneurial Learning: Exploring the Link Among Heuristics, Knowledge, and Action." Entrepreneurship Theory and Practice 33, no. 1 (2009): 167-192.

Holman, David, Karel Pavlica, and Richard Thorpe. 'Rethinking Kolb's Theory of Experiential Learning in Management Education The Contribution of Social Constructionism and Activity Theory.” Management Learning 28, no. 2 (1997): 135-148.

Jack, Sarah.. "Approaches to studying networks: implications and outcomes." Journal of Business Venturing 25, no. 1, (2010): 120-137.

Jack, Sarah, Susan Moult, Alisair R. Anderson, and Sarah Drakopoulou Dodd. "An Entrepreneurial Network Evolving: Patterns of Change." International Small Business Journal 28, no. 4 (2010): 315-337.

Jack, Sarah, Sarah Drakopoulou Dodd, and Alistair R Anderson. "Change and the Development of Entrepreneurial Networks over Time: a Processual Perspective." Entrepreneurship and Regional Development 20, no. 2 (2008): 125-159.

Jack, Sarah L., and Alistair R. Anderson. "The Effects of Embeddedness on the Entrepreneurial Process." Journal of Business Venturing 17, no. 5 (2002): 467487.

Jack, Sarah L, and Alistair R Anderson. "Entrepreneurship Education Within the Enterprise Culture: Producing Reflective Practitioners." International Journal of Entrepreneurial Behaviour \& Research 5, no. 3 (1999): 110-125.

Jenssen, Jan Inge, and Harold F Koenig. "The Effect of Social Networks on Resource Access and Business Start-ups." European Planning Studies 10, no. 8 (2002): 1039-1046.

Johannisson, Bengt. "Towards a Practice Theory of Entrepreneuring." Small Business Economics 36, no. 2 (2011): 135-150.

Johannisson, Bengt. "University Training for Entrepreneurship: Swedish Approaches." Entrepreneurship \& Regional Development 3, no. 1 (1991): 67-82.

Johannisson, Bengt, and Mette Mønsted. "Contextualizing Entrepreneurial Networking: The Case of Scandinavia." International Studies of Management \& Organization (1997): 109-136.

Kakavelakis, Konstantinos. "A Relational Approach to Understanding Knowing in Communities of Practice." Knowledge and Process Management 17, no. 4 (2010): 168-179.

Kim, Daniel H. "The Link Between Individual and Organizational Learning." The Strate gic Management of Intellectual Capital (1998): 41-62.

Knight, Louise, and Annie Pye. "Network Learning: An Empirically Derived Model of Learning by Groups of Organizations." Human Relations 58, no. 3 (2005): 369392.

Korsgaard, Steffen, and Alistair R Anderson. "Enacting Entrepreneurship as Social Value Creation." International Small Business Journal 29, no. 2 (2011): 135151. 
Krueger, Norris F. "What Lies Beneath? The Experiential Essence of Entrepreneurial Thinking." Entrepreneurship Theory and Practice 31, no. 1 (2007): 123-138.

Larson, Andrea. "Network dyads in entrepreneurial settings: a study of the governance of exchange relationships." Administrative Science Quarterly 37, no. 1 (1992):76-104.

Larson, Andrea, and Jennifer A Starr. "A Network Model of Organization Formation." Entrepreneurship Theory and Practice 17 (1993):5-5.

Lave, Jean, and Etienne Wenger. Situated Learning: Legitimate Peripheral Participation. Cambrid ge University Press, 1991.

Lebrasseur, Rolland, and Yves Robichaud. "Les Réseaux Formels de Relations Comme Facteur de Développement Économique." Revue Du Nouvel-Ontario 23 (1999).

Lechner, Christian, and Michael Dowling. "Firm Networks: External Relationships as Sources for the Growth and Competitiveness of Entrepreneurial Firms." Entrepreneurship \& Regional Development 15, no. 1 (2003): 1-26.

Lockett, Nigel, Ron Kerr, and Sarah Robinson. "Multiple Perspectives on the Challenges for Knowledge Transfer Between Higher Education Institutions and Industry.” International Small Business Journal 26, no. 6 (2008): 661-681.

Macpherson, Allan, and Robin Holt. "Knowledge, Learning and Small Firm Growth: a Systematic Review of the Evidence." Research Policy 36, no. 2 (2007): 172192.

Mäkinen, Helena. "Intra-firm and Inter-firm Learning in the Context of Start-up Companies." The International Journal of Entrepreneurship and Innovation 3, no. 1 (2002): 35-43.

McAdam, Rodney, William Keogh, Renee S Reid, and Neil Mitchell. "Implementing Innovation Management in Manufacturing SMEs: a Longitudinal Study." Journal of Small Business and Enterprise Development 14, no. 3 (2007): 385403.

McDermott, Richard. 'Learning Across Teams." Knowledge Management Review 8, no. 3 (1999): 32-36.

Merz, G Russell, Patricia B Weber, and Virginia B Laetz. "Linking Small Business Management with Entrepreneurial Growth." Journal of Small Business Management 32 (1994): 48-48.

Minniti, M., and W. Bygrave. "A Dynamic Model of Entrepreneurial Learning." Entrepreneurship Theory and Practice 25, no. 3 (2001):5-16.

Moingeon, Bertrand, Bertrand Quélin, Frédéric Dalsace, and Fabrice Lumineau. "Interorganizational Communities of Practice: Specificities and Stakes." Les Cahier de Recherche 857 (2006): 18.

Morris, Shad S., Warner P. Woodworth, and Shon R. Hiatt. "The Value of Networks in Enterprise Development: Case Studies in Eastern Europe and Southeast Asia." Journal of Developmental Entrepreneurship 11, no. 4 (2006): 345-356.

Oinas, Päivi. "Activity-specificity in Organizational Learning: Implications for Analysing the Role of Proximity." GeoJournal 49, no. 4 (1999):363-372.

Omrane, Amina, Alain Fayolle, and Olfa Zeribi-BenSlimane. "Les Compétences Entrepreneuriales et Le Processus Entrepreneurial: Une Approche Dynamique." La Revue Des Sciences de Gestion no. 5 (2011): 91-100.

Parker, Simon C. "The Economics of Formal Business Networks." Journal of Business Venturing 23, no. 6 (2008): 627-640.

Parkhe, Arvind, Stanley Wasserman, and David A Ralston. "New Frontiers in Network Theory Development." Academy of Management Review 31, no. 3 (2006): 560568. 
Pavlica, Karel, David Holman, and Richard Thorpe. "The Manager as a Practical Author of Learning." Career Development International 3, no. 7 (1998): 300307.

Politis, Diamanto. "The Process of Entrepreneurial Learning: a Conceptual Framework." Entrepreneurship Theory and Practice 29, no. 4 (2005):399-424.

Radu Lefebvre, Miruna, and Renaud Redien-Collot. “"How to Do Things with Words': The Discursive Dimension of Experiential Learning in Entrepreneurial Mentoring Dyads.” Journal of Small Business Management 51, no. 3 (2013): 370-393.

Rae, David. "Understanding Entrepreneurial Learning: a Question of How?" International Journal of Entrepreneurial Behaviour \& Research 6, no. 3 (2000): $145-159$.

Reuber, A Rebecca, and Eileen Fischer. 'Understanding the Consequences of Founders' Experience." Journal of Small Business Management 37, no. 2 (1999): 30-45.

Rogers, Mark. "Networks, Firm Size and Innovation." Small Business Economics 22, no. 2 (2004): 141-153.

Scarbrough, Harry, Jacky Swan, Stéphane Laurent, Mike Bresnen, Linda Edelman, and Sue Newell. "Project-based Learning and the Role of Learning Boundaries." Organization Studies 25, no. 9 (2004): 1579-1600.

Schatzki, Theodore R, Karin Knorr Cetina, and Eike von Savigny. The Practice Turn in Contemporary Theory. Routledge, 2001.

Schutjens, Veronique, and Erik Stam. "The Evolution and Nature of Young Firm Networks: a Longitudinal Perspective." Small Business Economics 21, no. 2 (2003): 115-134.

Scott, Jonathan M. "Gender and Entrepreneurship: a Multilevel Theory and Analysis." International Journal of Entrepreneurial Behaviour \& Research 15, no. 4 (2009): 386-388.

Singh, Robert, Gerald E Hills, Ralph C Hybels, and GT Lumpkin. "Opportunity Recognition through Social Network Characteristics of Entrepreneurs." Frontiers of Entrepreneurship Research (1999): 228-241.

Slotte-Kock, Susanna, and Nicole Coviello. "Entrepreneurship Research on Network Processes: A Review and Ways Forward." Entrepreneurship Theory and Practice 34, no. 1 (2010): 31-57.

Staber, Udo, and Howard E Aldrich. "Cross-National Similarities in the Personal Networks of Small Business Owners: A Comparison of Two Regions in North America." Canadian Journal of Sociology 20, no. 4 (1995).

Steier, Lloyd, and Royston Greenwood. "Newly Created Firms and Informal Angel Investors: a Four-stage Model of Network Development." Venture Capital: An International Journal of Entrepreneurial Finance 1, no. 2 (1999): 147-167.

St-Jean, Etienne, and Josée Audet. "The Role of Mentoring in the Learning Development of the Novice Entrepreneur." International Entrepreneurship and Management Journal 8, no. 1 (2012): 119-140.

Tajfel, Henri, and John C Turner. The Social Identity Theory of Intergroup Behavior. University of Toronto Press, 2004.

Tell, Joakim. "Learning Networks - A Metaphor for Inter Organizational Development in SMEs." Enterprise and Innovation Management Studies 1, no. 3 (September 2000): 303-317.

Theodorakopoulos, Nicholas, and Catarina Figueira. "What Can Situated Learning Theory Tell Us About Leading to Develop Organizational Learning Capabilities for Entrepreneurial Performance? Lessons from a Knowledge-Intensive Small 
Firm." Thunderbird International Business Review 54, no. 6 (2012): 859-873.

Thompson, Mark. "Structural and Epistemic Parameters in Communities of Practice." Organization Science 16, no. 2 (2005): 151-164.

Thorpe, Richard, Robin Holt, Allan Macpherson, and Luke Pittaway. "Using Knowled ge Within Small and Medium-sized Firms: A Systematic Review of the Evidence.” International Journal of Management Reviews 7, no. 4 (2005): $257-$ 281.

Tremblay, Maripier, and Camille Carrier. "Développement de La Recherche Sur L'identification Collective D'opportunités D'affaires: Assises et Perspectives.” Revue de l'Entrepreneuriat 5, no. 2 (2006): 69-88.

Vasilchenko, Elena, and Sussie Morrish. "The Role of Entrepreneurial Networks in the Exploration and Exploitation of Internationalization Opportunities by Information and Communication Technology Firms." Journal of International Marketing 19, no. 4 (2011): 88-105.

Verburg, Robert M., and Erik J.H. Andriessen. "A Typology of Knowledge Sharing Networks in Practice." Knowledge and Process Management 18, no. 1 (2011): 34-44.

Wenger, Etienne. "Communities of Practice and Social Learning Systems." Organization 7, no. 2 (May 1, 2000): 225-246.

Wenger, Etienne. "Communities of Practice: Learning as a Social System." Systems Thinker 9, no. 5 (1998). http://www.co-i-l.com/coil/knowledgegarden/cop/lss. shtml.

Wenger, Etienne, Richard McDermott, and William M Snyder. "Seven Principles for Cultivating Communities of Practice." Cultivating Communities of Practice: A Guide to Managing Knowledge 4 (2002).

Wenger, Etienne, Beverly Trayner, and Maarten de Laat. "Promoting and Assessing Value Creation in Communities and Networks: A Conceptual Framework." URL: Http //www. Knowledge-architecture. com/downloads/Wenger_Trayner_DeLaat_Value_creation. Pdf [July 25, 2011].

Wheeler, S Christian, Richard E Petty, and George Y Bizer. "Self-Schema Matching and Attitude Change: Situational and Dispositional Determinants of Message Elaboration.” Journal of Consumer Research 31, no. 4 (2005): 787-797.

Wilson, Fiona, Jill Kickul, Deborah Marlino, Saulo D Barbosa, and Mark D Griffiths. "An Analysis of the Role of Gender and Self-efficacy in Developing Female Entrepreneurial Interest and Behavior." Journal of Developmental Entrepreneurship 14, no. 2 (2009): 105-119.

Wincent, Joakim, Sara Thorgren, and Sergey Anokhin. "Managing Maturing Government-Supported Networks: The Shift from Monitoring to Embeddedness Controls." British Journal of Management (2012).

Wohlford, Kathryn E, John E Lochman, and Tammy D Barry. "The Relation Between Chosen Role Models and the Self-esteem of Men and Women." Sex Roles 50, no. 7-8 (2004): 575-582.

Xiao, Qian, Louis D Marino, and Weiling Zhuang. "A Situated Perspective of Entrepreneurial Learning: Implications for Entrepreneurial Innovation Propensity." Journal of Business \& Entrepreneurship 22, no. 1 (2010).

Yin, Robert K. Case Study Research: Design and Methods. Thousand Oaks, Calif: Sage Publications, 2003.

Yin, Robert K. "The Case Study Method as a Tool for Doing Evaluation." Current Sociology 40, no. 1 (1992): 121-137.

Zaheer, Akbar, and Natarjan Venkatraman. "Relational Governance as an 
Interorganizational Strategy: An Empirical Test of the Role of Trust in

Economic Exchange.” Strategic Management Journal 16, no. 5 (1995): 373-392. 


\section{Appendices}

\begin{tabular}{|c|c|c|c|c|c|}
\hline & Participant Observation & $\begin{array}{c}\text { Semi-di rected } \\
\text { intervie ws }\end{array}$ & Surveys & Internal Documents & Published Materials \\
\hline 2005 & $\begin{array}{l}\text { Business breakfast (1) } \\
\text { Board meeting (1) }\end{array}$ & $\begin{array}{l}\text { Net work manager } \\
\text { (2) }\end{array}$ & & $\begin{array}{l}\text { Electronic } \\
\text { correspondence }\end{array}$ & $\begin{array}{l}\text { Press release (1) } \\
\text { Internet presentations (1) } \\
\text { T V presentation (1) } \\
\text { Public presentations }(1)\end{array}$ \\
\hline 2006 & $\begin{array}{l}\text { Adhesion meetings (98) } \\
\text { Business breakfasts (10) } \\
\text { Board meeting (1) } \\
\text { Business dinners (1) } \\
\text { Reflection groups (3) }\end{array}$ & $\begin{array}{l}\text { Net work manager } \\
\text { (2) }\end{array}$ & & $\begin{array}{l}\text { New members' records } \\
(40) \\
\text { Attendance sheets (15) } \\
\text { Minutes (15) } \\
\text { Extranet } \\
\text { Electronic } \\
\text { correspondence }\end{array}$ & $\begin{array}{l}\text { E-newsletter (29) } \\
\text { Website } \\
\text { Internet presentations (4) } \\
\text { Press releases (2) } \\
\text { Public presentations(14) }\end{array}$ \\
\hline 2007 & $\begin{array}{l}\text { Adhesion meetings (81) } \\
\text { Business breakfasts }(8) \\
\text { Board meetings (2) } \\
\text { Business dinners (1) } \\
\text { Reflection groups (9) }\end{array}$ & $\begin{array}{l}\text { Net work manager } \\
\text { (2) }\end{array}$ & $\begin{array}{l}\text { Net work members } \\
\text { (22) }\end{array}$ & $\begin{array}{l}\text { New members' records } \\
\text { (44) } \\
\text { Attendance sheets (20) } \\
\text { Minutes (20) } \\
\text { Extranet } \\
\text { Electronic } \\
\text { correspondence }\end{array}$ & $\begin{array}{l}\text { E-newsletter (33) } \\
\text { Website } \\
\text { Web T V (2) } \\
\text { Public presentations (15) } \\
\text { Community of practice } \\
\text { meet ings of business support } \\
\text { professionals - Chamber of } \\
\text { Commerce (7) }\end{array}$ \\
\hline 2008 & $\begin{array}{l}\text { Adhesion meetings (149) } \\
\text { Business breakfasts (7) } \\
\text { Board meetings (2) } \\
\text { Business dinners (3) } \\
\text { Reflection groups (27) }\end{array}$ & $\begin{array}{l}\text { Net work manager } \\
\text { (2) }\end{array}$ & & $\begin{array}{l}\text { New members' records } \\
(31) \\
\text { Attendance sheets (14) } \\
\text { Minutes (14) } \\
\text { Extranet } \\
\text { Electronic } \\
\text { correspondence }\end{array}$ & $\begin{array}{l}\text { E-newsletter (36) } \\
\text { Website } \\
\text { Press releases (4) } \\
\text { Internet presentations (3) } \\
\text { TV presentation (1) } \\
\text { Public presentations (17) } \\
\text { Community of practice } \\
\text { meet ings of business support } \\
\text { professionals - Chamber of } \\
\text { Commerce(9) }\end{array}$ \\
\hline 2009 & $\begin{array}{l}\text { Adhesion meetings (23) } \\
\text { Business breakfasts (14) } \\
\text { Board meetings (1) } \\
\text { Business dinners (1) } \\
\text { Reflection groups (9) }\end{array}$ & $\begin{array}{l}\text { Net work manager } \\
\text { (2) }\end{array}$ & & $\begin{array}{l}\text { Members' records (6) } \\
\text { Attendance sheets (25) } \\
\text { Minutes (25) } \\
\text { Extranet } \\
\text { Electronic } \\
\text { correspondence }\end{array}$ & $\begin{array}{l}\text { E-newsletter (13) } \\
\text { Website } \\
\text { Press releases (2) } \\
\text { Public presentations (6) } \\
\text { Community of practice } \\
\text { meet ings of business support } \\
\text { professionals - Chamber of } \\
\text { Commerce (2) }\end{array}$ \\
\hline
\end{tabular}

Table 1. Data collection 


\begin{tabular}{|c|c|c|c|c|}
\hline & \multirow{3}{*}{$\begin{array}{c}\begin{array}{c}\text { Social Network } \\
\text { 'functionalist phase' } \\
\text { (cf. Jack et al. 2010) }\end{array} \\
\begin{array}{c}\text { Central } \\
\text { Initiator }\end{array}\end{array}$} & \multirow{3}{*}{$\begin{array}{c}\begin{array}{c}\text { Social and Economic Ne twork } \\
\text { 'instrumental phase' } \\
\text { (cf. Jack et al. 2010 }\end{array} \\
\text { Coordinator }\end{array}$} & \multirow{3}{*}{$\begin{array}{c}\begin{array}{c}\text { Community of Practice } \\
\text { 'altruist phase' } \\
\text { (cf. Jack et al. 2010) }\end{array} \\
\begin{array}{c}\text { Coordinator } \\
\text { Central for new members }\end{array}\end{array}$} \\
\hline & & & & \\
\hline \multirow{4}{*}{$\begin{array}{l}\text { Network } \\
\text { Components }\end{array}$} & $\begin{array}{l}\text { Role of the } \\
\text { Net work } \\
\text { Manager } \\
\end{array}$ & & & \\
\hline & $\begin{array}{l}\text { Locus of } \\
\text { Communication }\end{array}$ & Face to face meet ings & $\begin{array}{l}\text { Face to face meet ings within and } \\
\text { out side the net work } \\
\text { Distant communication }\end{array}$ & $\begin{array}{l}\text { Face to face meet ings within and } \\
\text { out side the net work } \\
\text { Distant communication } \\
\text { External business projects }\end{array}$ \\
\hline & $\begin{array}{l}\text { Entrance of new } \\
\text { members }\end{array}$ & $\begin{array}{l}\text { Net work Criteria } \\
\text { Net work Manager }\end{array}$ & $\begin{array}{l}\text { Net work Criteria } \\
\text { Net work tacit norms and rules }\end{array}$ & $\begin{array}{l}\text { Net work tacit norms and rules } \\
\text { Legitimate peripheral } \\
\text { participation }\end{array}$ \\
\hline & Nature of Ties & Weak Ties & $\begin{array}{l}\text { Weak and strong ties } \\
\text { Net work densification }\end{array}$ & $\begin{array}{l}\text { Net work densification } \\
\text { Strong and weak ties } \\
\text { Peripheral Participation }\end{array}$ \\
\hline \multicolumn{2}{|c|}{ Learning Processes } & $\begin{array}{l}\text { Knowledge sharing } \\
\text { Questioning, listening and } \\
\text { providing feed-back } \\
\text { (cf. St-Jean and Audet 2012) }\end{array}$ & $\begin{array}{l}\text { Explanation, advice and } \\
\text { guidance } \\
\text { Encouragement and emotional } \\
\text { support } \\
\text { (cf. St-Jean and Audet 2012) }\end{array}$ & $\begin{array}{l}\text { Role modeling } \\
\text { Develop common projects } \\
\text { (cf. St-Jean and Audet 2012) }\end{array}$ \\
\hline \multicolumn{2}{|c|}{ Learning Outcomes } & $\begin{array}{l}\text { Cognitive out comes } \\
\text { (enhanced knowledge of of } \\
\text { market and environment } \\
\text { issues) } \\
\text { Affective outcomes } \\
\text { (connection) } \\
\text { 'Becoming informed' and } \\
\text { 'becoming known' } \\
\text { (cf. Jack et al. 2010) }\end{array}$ & $\begin{array}{l}\text { Cognitive outcomes } \\
\text { (enhanced knowledge of market } \\
\text { and environment issues) } \\
\text { Affective outcomes (self- } \\
\text { confidence) } \\
\text { 'T apping into external } \\
\text { resources' and 'knowledge held } \\
\text { by others' } \\
\text { (cf. Jack et al. 2010) }\end{array}$ & $\begin{array}{l}\text { Skill-based knowledge } \\
\text { (use and implementation of } \\
\text { advice, solutions and insight sto } \\
\text { innovate and enhance } \\
\text { entrepreneurial pract ices) } \\
\text { Affective outcomes (shared } \\
\text { ident ity) } \\
\text { 'Finding new business', } \\
\text { 'maintaining existing business' } \\
\text { and 'making friends' } \\
\text { (cf. Jack et al. 2010) }\end{array}$ \\
\hline
\end{tabular}

Table 2. Longitudinal dynamics of network interaction and learning 